\title{
Evaluation of Salivary and Oral Cell Collection Methods for Genomic DNA Extraction
}

\author{
Clarissa Christina Avelar Fernandez ${ }^{1}$, Fernanda Farage da Costa Felipe Ferreira ${ }^{1}$, Christiane Vasconcellos Cruz ${ }^{1}$, Marcelo de Castro Costa ${ }^{1}$
}

${ }^{1}$ Department of Pediatric Dentistry and Orthodontics, Federal University of Rio de Janeiro, Brazil

\section{Abstract}

The use of saliva and oral cells as sources of biological material has gained attention, due to advantages such as facility, non-invasiveness, and great patient acceptance. The objective of the study was to compare four different types of saliva and oral buccal cell collecting methods for genomic DNA extraction: (1)Expectoration of saliva, (2)Expectoration of saliva with lingual stimulation, (3)Scraping with cytological brush, and (4)Scraping with cytological brush and expectoration of saliva. The sample was composed of students and employees from the Dental School of the Federal University of Rio de Janeiro ( $\mathrm{n}=20,10$ men and 10 women with mean age of $47.60 \pm 15.70$ and $20.50 \pm 2.1$, respectively). The collections were performed with an interval of at least one day between them and the participants were instructed to stay for less than 30 minutes without eating food and brushing teeth. Samples were stored at $-20^{\circ} \mathrm{C}$ until DNA extraction was performed using a commercially available kit (Qiagen $\left.{ }^{\circledR}\right)$. Differences in DNA yield between methods were test for statistical significance with an alpha of 0.05 . No sexual dimorphism was observed in relation to the concentration of DNA ( $p=0.76)$, age $(p=0.91)$, and ethnicities $(p=0.72)$. There was no significant difference between the collection methods in relation to the quantity and purity of the extracted DNA $(p \geq 0.05)$. Al methods gave lower DNA yields than the ones obtained from blood or saliva collected through comercial kits and may be carefully use for clinical diagnostic purposes or for research experiements requiring higher DNA concentrations.

\section{Introduction}

DNA for diagnostic or research purposes can be obtained from various biological materials. In the last decades, the DNA used in molecular studies was preferentially obtained from blood samples since they provide a large number of cells and, consequently, a good yield $[1,2]$. However, collection of blood samples has some drawbacks such as the potential non-viability in large populationbased studies. Because it is an invasive method, some patients may be resistant to collection, need a specialized professional to perform the procedure, and it is more difficult to perform in the elderly and children $[1,3,4]$. Another factor to be emphasized is that the ferrous ions $(\mathrm{Fe} 2+)$ present in the blood compete with $\mathrm{Mg} 2+$ ions, which are inhibitors of PCR (C-reactive protein) $[1,2]$.

Saliva has been increasingly used as a source of genomic DNA suitable for large studies because it is non-invasive and has diagnostic potential. In addition, when compared to the traditional method of collecting DNA from blood, it presents a reduced cost and is a noninvasive method that can be performed more easily in
Citation: Fernandez CCA, et al. (2019) Evaluation of salivary and oral cell collection methods for genomic DNA extraction. Dentistry 3000. 1:a001 doi:10.5195/d3000.2019.91

Received: May 17, 2019

Accepted: May 23, 2019

Published: July 25, 2019

Copyright: (C2019 Fernandez CCA, et al. This is an open access article licensed under a Creative Commons Attribution Work 4.0 United States License.

Email: pttpo2009@yahoo.com.br children, the elderly, and patients with special needs [5]. Collecting saliva also brings no risk of infections and has the potential to become a first line of clinical diagnosis [6].

A number of methods for collecting saliva and buccal cells have been reported: swabs, brushes, mouthwashes [4], drainage method, spit method, suction method, and stimulation by paraffin mastication and/or by applying citric acid to the tongue [6]. DNA quality is essential for the success rates in analyzes and the amount of DNA collected is extremely important and we must be attentive to these factors
(cc)BY

ULIS D-Sorle
New articles in this journal are licensed under a Creative Commons Attribution 4.0 United States License.

This journal is published by the University Library System, University of Pittsburgh as part of its D-Scribe Digital Publishing Program and is cosponored by the University of Pittsburgh Press. 
during the choice of DNA collection method [7].

Despite the obvious practicality and advantages of saliva and oral cells in obtaining DNA, there is a difference in the amount of DNA obtained depending on the method of extraction of genomic DNA from saliva used. The objective of the present study was to compare four different methods of collecting saliva and buccal cells for DNA extraction evaluation of its concentration and purity.

\section{Methods}

\section{SAMPLE SELECTION}

Twenty participants [10 males and 10 females, mean age of 36.55 $( \pm 15.74)$ years, 13 White and 7 Black] who were students and employees at the School of Dentistry of the Federal University of Rio de Janeiro were selected (convenience sample). The inclusion of these individuals occurred after they read and signed a Term of Free Consent. This project was approved by the Research Ethics Committee of the University Hospital Clementino Fraga Filho (HUCFF/UFRJ) number 619.096.

\section{DATA COLLECTION}

During the interview, data such as age, sex, and ethnicity were recorded. Then, four different protocols randomized for the order that they were performed were used for the collection of saliva and buccal cells by a single researcher (C.C.A.F.), with an interval of at least one day between each other. Participants were instructed to not smoke, eat and brush their teeth for at least 30 minutes before each saliva collection.

1. Expectoration of saliva;

2. Expectoration of saliva with lingual stimulus;

3. Scraping with a cytological brush; and,

4. Scraping with cytological brush + expectoration of saliva.

\subsection{Expectoration of saliva:}

Saliva collected was stored in a falcon tube. The researcher instructed each individual to spit until the marking of $2 \mathrm{ml}$. After the protocol collection was performed, information such as the date of the collection, the method and the study identifier the participant were recorded on the tube and it was protected by a plastic bag and stored at $-20^{\circ} \mathrm{C}$. This step was performed routinely in all the different protocols carried out in this research.

\subsection{Expectoration of saliva with}

lingual stimulus:

In this salivary collection method, the individuals were instructed to perform stimulation through the friction of their tongue against intraoral structures and after, they were asked to spit. Step by step, this method consisted of rubbing the tongue in the teeth, jugal mucosa, and roof of the mouth 10 times in each hemiarch in order to detach buccal cells from the oral mucosa.

\subsection{Scraping with a cytological} brush:

Scraping of buccal cells from the oral mucosa was performed with a cytological brush that was then stored in a Falcon tube. The procedure was performed by a single researcher (C.C.A.F.) who positioned the brush comfortably in the individual's mouth and rubbed the lower gum 10 times with rotational movements and back and forth.

\subsection{Scraping with a cytological} brush + expectoration of saliva: This method consisted of the combination of the methods Scraping with a cytological brush and Expectoration of saliva.

\section{DNA EXTRACTION}

To extract the DNA from the samples, the steps of the Qiagen ${ }^{\circledR}$ Kit proposed by the manufacturer were followed:

https://www.qiagen.com/br/qdm/alp/all prep-selection-

guide?intcmp=ECOM WEB SelectionGui des 2610 teaser Tools AllPrepGuide

\section{DNA QUANTIFICATION}

The concentration and purity of the DNA were determined by optical density spectrophotometer (NanoDrop ${ }^{\circledR}$ 2000c) using $2 \mu \mathrm{L}$ of the extracted material. The DNA concentration was evaluated at a wavelength of $260 \mathrm{~nm}$. The ratio between the values obtained at wavelengths $260 \mathrm{~nm}$ and $280 \mathrm{~nm}$ was used to estimate the purity of 
the genomic DNA. Only DNA

samples with a $260 / 280$ ratio

above 1.7 were considered satisfactory for DNA purity.

\section{STATISTICAL ANALYSIS}

Descriptive statistics were applied evaluating the frequency of sex, ethnicity and the mean age of all the studied individuals. One-way ANOVA and T-tests were used determine differences between groups. In addition, chi-square and/or Fisher's Exact test $(p \geq 0.05)$ were used to verify statistical differences in frequencies between the dichotomous variables. The data were tabulated and analyzed in the statistical software SPSS version 20.0 (Statistical Package for Social Sciences, SPSS Inc, Chicago, III) and all tests were carried out with a 95\% significance level.

\section{Results}

The mean concentration of genomic DNA was not different between males $[6.74 \quad( \pm 1.88)$ $\mathrm{ng} / \mu \mathrm{l}]$ and females $[6.88$ ( \pm 2.31$) n g / \mu l](p=0.76)$. This shows that there is no sexual dimorphism regarding the amount of genomic DNA recovered from saliva samples of females and males (Table 1).

The average amount of genomic DNA obtained from each method can be observed in Table 1 . There were no statistical differences between the methods.

\section{Discussion}

Table 1. Characterization of the sample in relation to age, ethnicity and its relationship with DNA concentration according to sex. ( ${ }^{*} p$ value $<0,001$.

$\mathrm{P}$-value obtained according to $\mathrm{T}$ - test $^{\mathrm{A}}$, Chi-square test ${ }^{\mathrm{B}}$ and ANOVA one-way test ${ }^{\mathrm{C}}$ )

\begin{tabular}{|c|c|c|c|c|}
\hline & Male & Female & Total & $p$ value \\
\hline $\begin{array}{l}\text { Age (土SD) } \\
\text { Ethnicity: N(\%) }\end{array}$ & $47.60 \pm 15.70$ & $25.50 \pm 2.18$ & $36.55 \pm 15.74$ & $\star A$ \\
\hline White & $4(40)$ & $9(90)$ & $13(65)$ & \\
\hline Black & $6(60)$ & $1(10)$ & $7(35)$ & $* \mathrm{~B}$ \\
\hline $\begin{array}{l}\text { DNA concentration } \pm S D \\
\text { Protocol of Saliva } \\
\text { Collection }\end{array}$ & $6.74 \pm 1.89$ & $6.89 \pm 2.31$ & $6.81 \pm 2.10$ & $0.57^{\mathrm{A}}$ \\
\hline Expectoration of saliva & $5.73 \pm 1.36$ & $5.06 \pm 1.28$ & $5.39 \pm 1.33$ & \\
\hline $\begin{array}{l}\text { Expectoration of saliva with } \\
\text { lingual stimulus }\end{array}$ & $5.66 \pm 1.66$ & $7.40 \pm 3.70$ & $6.53 \pm 2.93$ & \\
\hline $\begin{array}{l}\text { Scraping with a cytological } \\
\text { brush }\end{array}$ & $8.10 \pm 1.56$ & $7.89 \pm 1.02$ & $8 \pm 1.29$ & \\
\hline $\begin{array}{l}\text { Scraping with cytological } \\
\text { brush }+ \text { expectoration of } \\
\text { saliva }\end{array}$ & $7.47 \pm 1.80$ & $7.19 \pm 1.26$ & $7.33 \pm 1.52$ & $0.68^{C}$ \\
\hline
\end{tabular}

The four methods of saliva and buccal cell collection did not show DNA yield differences but the values obtained are remarkably lower than the ones obtained from kit-based saliva collection methods [8].

Most of the studies reported in the literature collected buccal cells and saliva in three ways: rubbing or scraping the oral mucosa with cytological brushes, mouthwash with oral solution and saliva expectoration $[1,3,9,10]$. The collections are performed through commercial kits and the details of each methodology depend on to the manufacturers' instructions. The most commonly used commercial kit is Oragene ${ }^{\circledR}$ (DNA Genotek) where assessed individuals need only expectorate in a small bottle. When the bottle is closed, a solution containing bactericidal substances mix with the saliva and preserve the DNA, allowing the sample to be held for several months at room temperature. This kit has presented favorable amounts of genomic DNA and is easy to apply, allowing even self-collection $[5,7,11,12]$. On the other hand, Oragene $^{\circledR}$ kit is expensive, which represents a disadvantage in 
studies with a large sample. In our study, we did not use a method that included a commercial saliva collection kit, however DNA concentrations obtained were much lower in comparison to these commercial saliva collection kits $^{8}$ and this suggests these protocols potentially will not allow for analyses that require higher DNA concentrations.

All methods gave lower DNA yields than the ones obtained from blood or saliva collected through comercial kits and may be carefully use for clinical diagnostic purposes or for research experiements requiring higher DNA concentrations.

\section{Acknowledgements}

The authors are indebted to the participants of the study.

\section{References}

1. Avaliação do rendimento, pureza e integridade do DNA genômico em diferentes protocolos de coleta de células bucais. Waltrick-Zambuzzi MR, Vieira, TCS, Romanos HF, Macedo EE, Granjeiro JM, Kuchler EC. Int J Dent, Recife. 2012 jan/mar; 11(1):12-18.

2. Comparison of different collection procedures and two methods for DNA isolation from saliva. Durdiaková J, Kamodyivá N, Ostatníková D, Vlková B, Celec P. Clin Chem Lab Med. 2012; 50(4):643647.

3. Determinants of DNA yield and purity collected with buccal cell samples. Van Wieren-de Wijer DBMA, Maitland-van der Zee AH, de Boer A, Belitser SV, Kroon $A A$, de Leeuw PW, Schiffers $P$, Janssen RGJH, van Duijn CM, Stricker BHCH, Klungel $\mathrm{OH}$. Eur J Epidemiol. 2009; 24: 677-682.

4. Comparison of methods for collection of DNA samples by mail in the black women's helth study. Cozier YC, Palmer JR, Rosenberg L. Ann Epidemiol. 2004; V. 14, P.117122.

5. DNA yeld and quality of saliva samples and suitability for large-scale epidemiological studies in children. Koni AC, Scott RA, Wang G, Bailey MES, Peplies J, Bammann K, Pirsiladis YP. Internt Journ of Obes. 2011; V. 35. P 113-118.

6. Diagnostic potential of saliva: current state and future applications. Pfaffe T, CooperWhite J, Beyerlein P, Kosner K, Punyadeera C. Clinc Chem. 2011; V. 57. P 675-687.

7. Quality and quantity of saliva DNA obtained from the selfadministrated oragene method - a pilot study on the cohort of swedish men. Rylander-Rudqvist $T$, Hankansson N, Tybring G, Wolk, Alicja. Cancer Epidemiol Biomarkers Prev. 2006;15(9).

8. Comparative study of five commercially avaiable saliva collection kits for DNA extraction. Deeley K, Noel J, Vieira ARClin Lab. 2016; 1;62(9):1809-1813.
9. Collection of buccal cell DNA in seventh-grade children using water and a toothbrush. London SJ, Xia J, Lehman TA, Yang J, Granada E, Chunhong L, Dubeau L, Li T, David-Beabes GL, Li Y. Canc Epid Biom Prev, 2001; v.10, p.1227-1230.

10. Quality of DNA extracted from saliva samples collected with the Oragene DNA selfcollection kit. Nuner AP, Oliveira IO, Santos BR, Millech C, Silva LP, González DA, Hallal PC, Menezes AMBB, Araújo CL, Barros F. Med Reserch Method. 2012.

11. Collection of blood, saliva and buccal cell samples in a pilot study on the danish nurse cohort: comparison of the response rate and quality of genomic DNA. Hansen TO, Simonsen MK, Nielsen FC, Hundrup YA. Cancer Epidemiol Biomarkers Prev. 2007; V. 16. P.2072-2076.

12. Buccal DNA collection: comparison of buccal swabs with FTA cards. Milne E, Bockxmeer FMV, Robertson L, Brisbane JM, Ashton LJ, Scott RJ, Armstrong BK. Canc Epid Biom Prev. 2006; V.15. P. 816819. 